\title{
Transfer of monoclonal antibodies into breastmilk in neurologic and non-neurologic diseases
}

Sara C. LaHue, MD, Annika Anderson, BA, Kristen M. Krysko, MD, MAS, Alice Rutatangwa, DO, Morna J. Dorsey, MD, MMSc, Thomas Hale, RPh, PhD, Uma Mahadevan, MD, Elizabeth E. Rogers, MD, Melissa G. Rosenstein, MD, MAS, and Riley Bove, MD, MSc

Neurol Neuroimmunol Neuroinflamm 2020;7:e769. doi:10.1212/NXI.0000000000000769

\section{Abstract}

\section{Objective}

To review currently available data on the transfer of monoclonal antibodies (mAbs) in the breastmilk of women receiving treatment for neurologic and non-neurologic diseases.

\section{Methods}

We systematically searched the medical literature for studies referring to 19 selected $\mathrm{mAb}$ therapies frequently used in neurologic conditions and "breastmilk," "breast milk," "breastfeeding," or "lactation." From an initial list of 288 unique references, 29 distinct full-text studies met the eligibility criteria. One additional study was added after the literature search based on expert knowledge of an additional article. These 30 studies were reviewed. These assessed the presence of our selected mAbs in human breastmilk in samples collected from a total of 155 individual women.

\section{Results}

Drug concentrations were typically low in breastmilk and tended to peak within 48 hours, although maximum levels could occur up to 14 days from infusion. Most studies did not evaluate the breastmilk to maternal serum drug concentration ratio, but in those evaluating this, the highest ratio was 1:20 for infliximab. Relative infant dose, a metric comparing the infant with maternal drug dose $(<10 \%$ is generally considered safe), was evaluated for certolizumab $(<1 \%)$, rituximab $(<1 \%)$, and natalizumab (maximum of 5.3\%; cumulative effects of monthly dosing are anticipated). Importantly, a total of 368 infants were followed for $\geq 6$ months after exposure to breastmilk of mothers treated with mAbs; none experienced reported developmental delay or serious infections.

\section{Conclusions}

The current data are reassuring for low $\mathrm{mAb}$ drug transfer to breastmilk, but further studies are needed, including of longer-term effects on infant immunity and childhood development.

\author{
Correspondence \\ Dr. Bove \\ riley.bove@ucsf.edu
}




\section{Glossary}

ADA = adalimumab; BVZ = bevacizumab; FcR = Fc receptor; $\mathbf{G O L}=$ golimumab; IBD = inflammatory bowel disease; IPI = ipilimumab; $\mathbf{m A b}=$ monoclonal antibody; NAT = natalizumab; NMOSD = neuromyelitis optica spectrum disorder; RA = rheumatoid arthritis; $\mathbf{R B Z}=$ ranibizumab; RID = relative infant dose; $\mathbf{R T X}=$ rituximab; TNFi $=$ TNF inhibitors; $\mathbf{T C Z}=$ tocilizumab; UST = ustekinumab; VDZ = vedolizumab.

Monoclonal antibodies (mAbs) are increasingly used to treat autoimmune conditions that affect women who may become pregnant or breastfeed. These conditions span various subspecialties, and many are neurologic including migraine, myasthenia gravis, MS, neuromyelitis optica spectrum disorder (NMOSD), and autoimmune encephalitis. ${ }^{1-6}$ However, the optimal treatment of these women during the peripartum period remains uncertain. ${ }^{7}$ Although immunoglobulin (Ig) A is the primary immunoglobulin in human breastmilk due to transport mechanisms, ${ }^{8,9}$ IgG-based mAbs with large molecular sizes and limited transport mechanisms are largely precluded from transfer into breastmilk. ${ }^{9}$ Most immunoglobulins have low oral bioavailability, which reduces the likelihood of absorption by breastfeeding infants ${ }^{8}$ to less than $25 \%{ }^{10}$ It is generally recognized that secretory IgA, the primary class of Ig in human breastmilk, is stable against enzymatic degradation. ${ }^{10}$ The neonatal $\mathrm{Fc}$ receptor $(\mathrm{FcR})$ could allow passage of some undigested $\operatorname{IgG}$ molecules into the neonatal circulation, although it may be stripped from the IgG during passage through the gut. ${ }^{11}$ Limited safety data on the use of mAbs during breastfeeding have resulted in women being advised to either forego breastfeeding despite strong evidence for maternal and neonatal benefits from breastfeeding ${ }^{12}$ or forego treatment until weaning.

Recently, several studies investigated this research gap and provided evidence-based recommendations for women who may benefit from treatment with $\mathrm{mAbs}$ in the peripartum period and concluded that biologic therapies used in inflammatory bowel disease (IBD) are compatible with breastfeeding. ${ }^{13,14}$ Here, we performed a narrative review to assess current knowledge about the transfer of $\mathrm{mAbs}$ in breastmilk.

\section{Methods}

The bibliographic databases PubMed and EMBASE were queried from inception through April 7, 2019. The reference lists from each medication entry in the Drugs and Lactation Database (LactMed) were also reviewed from inception through May 11, 2019. The search located terms in either the article title or abstract contents in PubMed and EMBASE. We included mAbs used in the treatment of neurologic autoimmune diseases, as well as other non-neurologic conditions such as rheumatoid arthritis (RA) or IBD. The following $m A b$ search terms were included: "adalimumab," "alemtuzumab," "bevacizumab," “certolizumab," "daclizumab," "eculizumab," "erenumab," "fremanezumab," "galcanezumab," "golimumab," “infliximab," “natalizumab," “ocrelizumab," “ofatumumab," "rituximab," "satralizumab," "tocilizumab," "ustekinumab," and "vedolizumab." The term "monoclonal antibody" was also searched in an effort to find additional articles discussing the aforementioned $\mathrm{mAbs}$, additional $\mathrm{mAbs}$, and general concepts pertaining to mAbs. The following search terms were used in combination with each of the mAb terms previously listed: "breastmilk," "breast milk," "breastfeeding," or "lactation." A medical librarian assisted with the structure of this search.

Studies were included if they examined the use of $\mathrm{mAb}$ therapies in human breastmilk, published in English with full text available. Studies with data derived solely from animal models, or available only in abstract form, were excluded.

When available, we extracted the following data: (1) absolute average and (2) maximum absolute mAb dose to the infant in a 24-hour period and (3) relative infant dose (RID) $)^{15}$ (see table 1 for calculations). Data on the clinical condition studied, treatment details, breastfeeding details, and pregnancy and infant outcomes were collected when available.

\section{Results}

The search yielded a total of 529 references (figure). One additional study was added after the literature search based on expert knowledge of an additional article published after May 11, 2019. After duplicates were removed, 289 references were screened by title and abstract review (S.L. and R.B.). A total of 62 full-text studies were assessed for eligibility, and 30 studies were included (S.L. and R.B.). Data were extracted (A.A.) and checked (R.B. and K.K.) for individual study-level information relating to measurement of $\mathrm{mAb}$ in breastmilk (table 2). No relevant studies were found for the following mAbs: alemtuzumab, daclizumab, erenumab, fremanezumab, galcanezumab, ocrelizumab, ofatumumab, and satralizumab. Data on the use of ipilimumab (IPI) and ranibizumab were found in the process of study review.

\section{CD20 inhibitors: rituximab}

A single case study of 1 mother with granulomatosis with polyangiitis and a prospective registry, which included 9 mothers with MS, investigated the presence of rituximab (RTX) in breastmilk. ${ }^{16,17}$ Across both studies, 5 mothers conceived within 6 months of their last RTX infusion; all 10 women resumed or initiated RTX within 1.5-11 months after delivery. All 10 women provided breastmilk, a total of 34 samples ( 5 with serial samples), collected from 8 hours to 90 days postinfusion. Six 
Table 1 Calculations used to measure antibody content in breastmilk

\begin{tabular}{ll}
\hline Measure & Calculation \\
\hline Absolute average monoclonal antibody dose to the infant in a 24-hour period & Multiply $\mathrm{C}_{\text {avg }}$ by $150 \mathrm{cc} / \mathrm{kg} / \mathrm{d}$. \\
\hline Maximum absolute monoclonal antibody dose to the infant in a 24-hour period & Multiply $\mathrm{C}_{\max }$ by $150 \mathrm{cc} / \mathrm{kg} / \mathrm{d}$. \\
\hline $\begin{array}{l}\text { Relative infant dose (RID), which estimates the infant's exposure to monoclonal } \\
\text { antibody as a percentage of the maternal dose over a 24-hour period }\end{array}$ & $\begin{array}{l}\text { Multiply } \mathrm{C}_{\text {avg }} \text { in } \mathrm{mg} / \mathrm{L}, \text { by } 0.15 \mathrm{~L} / \mathrm{kg} / \mathrm{d} \text { of breastmilk and by the } \\
\text { maternal weight, then divide by the maternal dose. }\end{array}$ \\
\hline
\end{tabular}

mothers elected to continue breastfeeding after RTX treatment. ${ }^{16,17}$ Although present in all samples, the concentration of RTX was minimal, with the maximum concentration of $0.6 \mu \mathrm{g} / \mathrm{mL}$ observed 8 days postinfusion. ${ }^{16}$ One study determined a low milk/serum ratio of 1:240 of RTX in breastmilk relative to maternal serum. ${ }^{16}$ The maximum RID of $0.33 \%$ was observed in a single sample provided 11 days postinfusion, although among women with serial samples, the median RID was $0.08 \%$ (range $0.06-0.10 \%$ ), and estimated 24-hour infant dose was $9.4 \mu \mathrm{g} / \mathrm{kg} / \mathrm{d}$ (based on $\mathrm{C}_{\text {avg }}$ in breastmilk). ${ }^{17}$ Five of the 6 infants breastfed after maternal treatment with RTX were followed between 8 and 18 months with normal development, no serious infections, and routine vaccination (vaccination schedule only reported for 4 infants ${ }^{17}$ ).

\section{Complement protein $\mathrm{C}$ inhibitors: eculizumab}

One prospective study of eculizumab during pregnancy and breastfeeding followed 75 pregnancies in 61 mothers with paroxysmal nocturnal hemoglobinuria. ${ }^{18}$ Forty-five of 46 mothers treated before conception continued treatment

Figure Flow diagram of study identification and inclusion as according to PRISMA 2009 guidelines

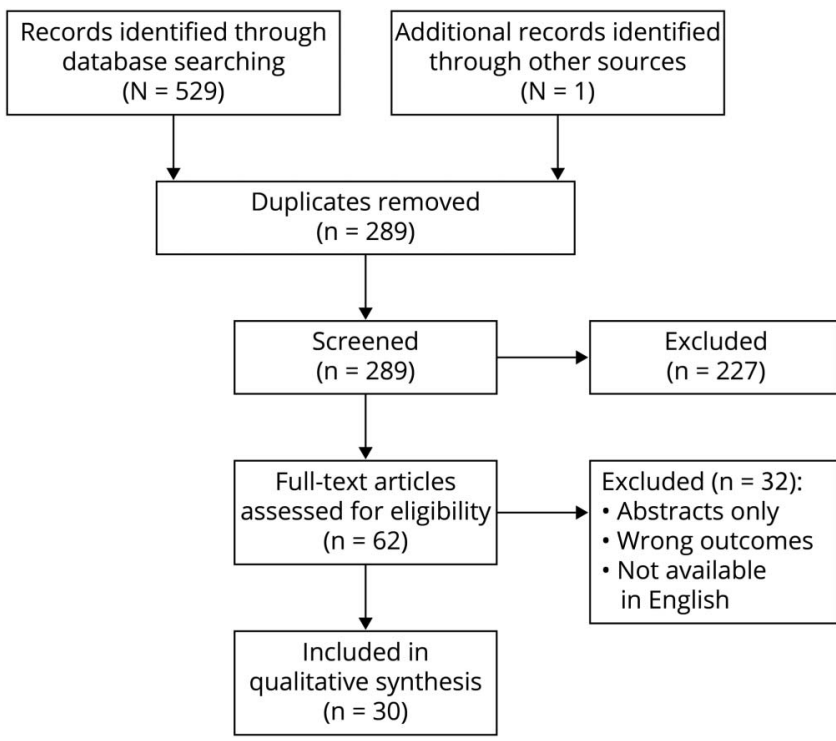

The database search yielded a total of 529 references, which were screened for duplicates, full-text availability, and content; 30 studies screened eligible for inclusion in the review. throughout pregnancy, and 29 mothers initiated eculizumab during the second or third trimester and continued postpartum. Measurable eculizumab was detected in 7 of 20 cord blood samples with a concentration ranging from 11.8 to $21.2 \mu \mathrm{g} / \mathrm{mL}$. Twenty-five infants were breastfed following maternal eculizumab treatment, and 10 mothers provided a single breastmilk sample posttreatment: none showed detectable eculizumab $(5 \mu \mathrm{g} / \mathrm{mL}$ lower limit of detection). Sixtyfour infants were formally followed up to 12 months of age; the number of these infants breastfed following maternal treatment was not specified. All infants were healthy and reached normal developmental milestones with the exception of 2 infants: one with asymptomatic neutropenia after delivery and another with slightly delayed speech, and for whom breastfeeding status was not reported.

\section{CTLA-4 inhibitors: ipilimumab}

IPI during breastfeeding was prospectively evaluated in 1 woman treated for metastatic melanoma. ${ }^{19}$ A course of 4 IPI infusions administered at $3 \mathrm{mg} / \mathrm{kg}$ every 3 weeks was initiated postpartum, and breastfeeding was temporarily discontinued until 3 weeks after the final infusion. The mother provided breastmilk serially sampled up to 25 days postinitiation of treatment. Although IPI was detectable in all samples, the concentration reached a Cmax of $0.147 \mu \mathrm{g} / \mathrm{mL}$ at 4 days after the second infusion ( 21 days posttreatment initiation) with a notable increase at repeat infusion. ${ }^{19}$ An estimated infant exposure of $53.481 \mu \mathrm{g} / \mathrm{d}$ was calculated based on the average IPI concentration available in breastmilk and average breastmilk intake by infants within 24 hours. Based on this potential exposure, a concern for cumulative toxicity was noted, given that over the course of 12 weeks of treatment, the potential infant exposure would reach approximately $4500 \mu \mathrm{g} / \mathrm{mL}$.

\section{Integrin inhibitors: vedolizumab ( $\alpha 4 \beta 7)$ and natalizumab (a4)}

\section{Vedolizumab}

Two cohort studies prospectively followed a combined 13 pregnancies in women with IBD treated with vedolizumab (VDZ) during breastfeeding. ${ }^{20,21}$ All 13 mothers elected to continue breastfeeding after VDZ treatment, and 10 provided breastmilk, serially sampled between 30 minutes and up to 15 days postinfusion. Before the infusion at which breastmilk collection occurred, all mothers had received infusions at an earlier time point. Minimal concentrations of VDZ were observed in all samples, with the highest concentration of 
Table 2 Summary of studies reporting measurement of monoclonal antibody (mAb) therapies in breastmilk in women with chronic conditions treated during pregnancy and breastfeeding

\begin{tabular}{|c|c|c|c|c|c|c|}
\hline mAb (target) & $\begin{array}{l}\text { Neurology } \\
\text { use }\end{array}$ & Study types & Condition & $\mathbf{N}^{\mathrm{a}}$ & $\begin{array}{l}C_{\max } \text { in } B M \text { (range) } \\
\mu \mathrm{g} / \mathrm{mL}\end{array}$ & $\begin{array}{l}\text { Infant dose } \\
\text { from BM }\end{array}$ \\
\hline \multirow[t]{4}{*}{ Adalimumab (TNF-a) } & NA & Case report ${ }^{31}$ & $\mathrm{CD}$ & NA & NR & $\begin{array}{l}\text { Not detected in infant } \\
\text { serum at } 3 \text { months }\end{array}$ \\
\hline & & Case report ${ }^{32}$ & $C D$ & 1 & $0.031(N A)$ & NR \\
\hline & & Prospective ${ }^{24}$ & IBD & 21 & $0.71(0.45-0.71)$ & NR \\
\hline & & Prospective $^{33}$ & IBD & 2 & $0.00488(0.00483-0.00488)$ & $\begin{array}{l}8.4 \mu \mathrm{g} / \mathrm{mL} \text { in infant } \\
\text { serum at } 1 \text { day }^{\mathrm{b}}\end{array}$ \\
\hline \multirow[t]{3}{*}{ Bevacizumab (VEGF-A) } & Glioblastoma & Case report ${ }^{43}$ & CNV & NA & NR & NR \\
\hline & & Case report ${ }^{44}$ & CNV & 1 & Not detected & NR \\
\hline & & Case series $^{45}$ & CNV & 2 & Not detected & NR \\
\hline \multirow[t]{4}{*}{ Certolizumab (TNF-a) } & NA & Case report ${ }^{35}$ & RA & 1 & Not detected & $\begin{array}{l}\text { Not detected in infant } \\
\text { serum at } 3 \text { days }\end{array}$ \\
\hline & & Case series $^{36}$ & $\mathrm{RA} / \mathrm{SpA}$ & 2 & Not detected & NR \\
\hline & & Cohort study ${ }^{34}$ & $\begin{array}{l}\text { RA/CD/ } \\
\text { axSpA/PsA }\end{array}$ & 17 & $0.076(0.032-0.076)$ & $\begin{array}{l}\text { RID (range) } 0.15 \% \\
(0.04-0.30)\end{array}$ \\
\hline & & Prospective $^{24}$ & IBD & 13 & $0.29(0.27-0.29)$ & NR \\
\hline Eculizumab (C5) & MG/NMOSD & Prospective $^{18}$ & $\mathrm{PNH}$ & 10 & Not detected & NR \\
\hline Golimumab (TNF- $\alpha$ ) & NA & Prospective ${ }^{24}$ & IBD & 1 & Not detected & NR \\
\hline Ipilimumab (CTLA-4) & NA & Case report ${ }^{19}$ & Melanoma & 1 & 0.147 (NA) & $\begin{array}{l}\text { Estimated infant } \\
\text { dose } 53.48 \mu \mathrm{g} / \mathrm{d}\end{array}$ \\
\hline \multirow[t]{8}{*}{ Infliximab (TNF- $\alpha$ ) } & Neurosarcoidosis & Case Report ${ }^{37}$ & $\mathrm{CD}$ & 1 & Not detected & NR \\
\hline & & Case report ${ }^{38}$ & $\mathrm{CD}$ & 1 & Not detected & $\begin{array}{l}C_{\max } \text { in infant } \\
\text { serum } 39.5 \mu \mathrm{g} / \mathrm{mL}\end{array}$ \\
\hline & & Case report ${ }^{39}$ & Psoriasis & NA & NR & NR \\
\hline & & Case series $^{40}$ & IBD & 3 & $0.300(0.130-0.300)$ & $\begin{array}{l}\text { Absolute infant } \\
\text { dose } 0.15 \mathrm{mg} / \mathrm{kg} / \mathrm{d}\end{array}$ \\
\hline & & Case series $^{41}$ & $\mathrm{CD}$ & 3 & Not detected & $\begin{array}{l}\text { Not detected in } \\
\text { infant serum }\end{array}$ \\
\hline & & Cohort study ${ }^{42}$ & $\mathrm{CD}$ & 3 & $0.105(0.02-0.105)$ & NR \\
\hline & & Prospective ${ }^{24}$ & IBD & 29 & $0.74(0.15-0.74)$ & NR \\
\hline & & Prospective $^{33}$ & IBD & 2 & $0.2(0.120-0.2)$ & $\begin{array}{l}\text { Infant serum } 5 \mathrm{~d} \\
\text { post-IFX } 1.7 \mu \mathrm{g} / \mathrm{mL}\end{array}$ \\
\hline \multirow[t]{3}{*}{ Natalizumab (a-4 integrin) } & MS & Case report ${ }^{22}$ & MS & 1 & $2.83(\mathrm{NA})$ & $\begin{array}{l}\text { RID } 1.74 \%\left(C_{\text {avg }}\right) \\
5.30 \%\left(C_{\text {max }}\right)\end{array}$ \\
\hline & & Cohort study ${ }^{23}$ & MS & 4 & $0.412(0.02-0.412)$ & NR \\
\hline & & Prospective ${ }^{24}$ & IBD & 2 & $0.46(\mathrm{NA})$ & NR \\
\hline Ranibizumab (VEGF-A) & Glioblastoma & Case report ${ }^{44}$ & CNV & NA & NR & NR \\
\hline \multirow[t]{2}{*}{ Rituximab (CD20) } & $\begin{array}{l}\text { MS/NMOSD/ } \\
\text { MG/AE }\end{array}$ & Case report ${ }^{16}$ & GPA & 1 & $0.6(N A)$ & NR \\
\hline & & Prospective ${ }^{17}$ & MS & 9 & $0.074(0.061-0.29)$ & $\begin{array}{l}\text { RID (range) } 0.08 \% \\
(0.06-0.10 \%)\end{array}$ \\
\hline \multirow[t]{2}{*}{ Tocilizumab (IL-6 receptor) } & NMOSD & Case report ${ }^{25}$ & AOSD & 1 & 0.215 (NA) & $\begin{array}{l}\text { Not detected in infant } \\
\text { serum at } 4 \text { weeks }\end{array}$ \\
\hline & & Case series $^{26}$ & RA & 2 & $0.148(0.068-0.148)$ & NR \\
\hline
\end{tabular}


Table 2 Summary of studies reporting measurement of monoclonal antibody (mAb) therapies in breastmilk in women with chronic conditions treated during pregnancy and breastfeeding (continued)

\begin{tabular}{|c|c|c|c|c|c|c|}
\hline mAb (target) & $\begin{array}{l}\text { Neurology } \\
\text { use }\end{array}$ & Study types & Condition & $\mathbf{N}^{a}$ & $\begin{array}{l}C_{\max } \text { in } B M(\text { range) } \\
\mu g / m L\end{array}$ & $\begin{array}{l}\text { Infant dose } \\
\text { from BM }\end{array}$ \\
\hline & & Retrospective ${ }^{28}$ & $\begin{array}{l}\text { RA/SJIA/ } \\
\text { PJIA/MCD }\end{array}$ & NA & NR & NR \\
\hline & & Cohort study ${ }^{27}$ & RA/AOSD & 4 & $0.113(0.068-0.205)$ & NR \\
\hline \multirow{3}{*}{$\begin{array}{l}\text { Ustekinumab } \\
\text { (IL-12 and -23) }\end{array}$} & NA & Case report ${ }^{30}$ & Psoriasis & NA & NR & NR \\
\hline & & Case report ${ }^{29}$ & $C D$ & 1 & $3.2(\mathrm{NA})$ & NR \\
\hline & & Prospective $^{24}$ & IBD & 6 & $1.57(0.72-1.57)$ & NR \\
\hline \multirow[t]{2}{*}{ Vedolizumab ( $\alpha 4 \beta 7$ ) } & NA & Cohort study ${ }^{21}$ & IBD & 5 & $0.478(0.108-0.478)$ & NR \\
\hline & & Cohort study ${ }^{20}$ & IBD & 5 & $0.318(0.196-0.318)$ & $\begin{array}{l}\text { Max }_{\text {abs }} 24 \text {-hour infant dose } \\
0.048 \mathrm{mg} / \mathrm{kg}\end{array}$ \\
\hline
\end{tabular}

Abbreviations: $\mathrm{AE}$ = autoimmune encephalitis; $\mathrm{AOSD}=$ adult-onset Still disease; axSpA = axial spondyloarthritis; $\mathrm{BF}=$ breast feeding; $\mathrm{BM}=$ breastmilk; $\mathrm{CD}=$ Crohn disease; $\mathrm{CNV}$ = choroidal neovascularization; GA = gestational age; GPA = granulomatosis with polyangiitis; IBD = inflammatory bowel disease; IFX = infliximab; $\mathrm{mAb}=$ monoclonal antibody; $\mathrm{MCD}=$ multicentric Castleman disease; $\mathrm{MG}=$ myasthenia gravis; $\mathrm{NA}$ = not applicable; NMOSD = neuromyelitis optica spectrum disorder; NR = not reported or not performed; PJIA = polyarticular juvenile idiopathic arthritis; PNH = paroxysmal nocturnal hemoglobinuria; PsA = psoriatic arthritis; RA = rheumatoid arthritis; RID = relative infant dose; SJIA = systemic juvenile idiopathic arthritis; SpA = spondyloarthritis; TNF = tumor necrosis factor; UC = ulcerative colitis; URTI = upper respiratory tract infection; UTI = urinary tract infection; VEGF-A = vascular endothelial growth factor A. All therapies are IgG1 subclass except eculizumab (hybrid IgG2/G4) and natalizumab (IgG4). Full details are available in table e-1, links.Iww.com/NXI/A260.

a Number of who provided breastmilk samples.

b Gestational exposure.

$0.478 \mu \mathrm{g} / \mathrm{mL}$ observed 3 to 4 days postinfusion. ${ }^{21}$ The ratio of maximum vedolizumab concentration in breastmilk was calculated to be less than $1 \%$ of the concentration in maternal serum. ${ }^{20}$ All 13 infants were followed up to 10 months of age and were found to have normal development, routine vaccinations, and no serious infections. ${ }^{20,21}$

\section{Natalizumab (IgG4)}

Unlike most other mAbs, natalizumab (NAT) is an IgG4 subclass. There are 3 prospective studies of safety of NAT during breastfeeding in women treated for $\mathrm{MS}^{22,23}$ or IBD. ${ }^{24}$ Cumulatively, 13 infants were breastfed following maternal resumption of NAT postpartum. Seven of these nursing mothers provided breastmilk samples between 1 hour and up to 50 days following the first postpartum infusion; several mothers gave multiple samples after 2 and up to 5 maintenance infusions. NAT was detectable as early as 12 hours, ${ }^{24}$ and a notable increase in concentration over time with repeat infusions was observed. ${ }^{22,23}$ The highest concentration, $2.83 \mu \mathrm{g} / \mathrm{mL}$, was observed 21 days after a second postpartum NAT infusion (and 50 days after the first infusion). ${ }^{22}$ In this study, maximal RID was calculated as $5.30 \%$ (based on the peak concentration) and $1.74 \%$ (based on the average concentration). ${ }^{22} \mathrm{~A}$ risk for accumulation of NAT in breastmilk in women receiving multiple infusions was identified in 2 studies, providing a rationale for longer duration of follow-up. ${ }^{22,23}$ Longitudinal infant outcomes at 12 months were assessed in a pooled cohort comparing development and infection rate according to breastfeeding status in 824 infants whose mothers were treated with various $\mathrm{mAbs}$, including 12 treated with NAT, 8 of whom breastfed posttreatment, with no significant risk observed overall. ${ }^{24}$

\section{Interleukin inhibitors: tocilizumab (IL-6) and ustekinumab (IL-12 and IL-23)}

\section{Tocilizumab}

Three prospective studies evaluated the safety of tocilizumab (TCZ) during pregnancy and breastfeeding for a total of 7 pregnancies in women treated for RA and adult-onset Still disease. ${ }^{25-27}$ In all 7 women, TCZ was either stopped during the first trimester or continued throughout pregnancy; all resulted in term delivery of healthy infants. Infant serum was collected at delivery in 1 pregnancy with a low, but detectable, TCZ concentration attributed to placental transfer. ${ }^{25}$ All 7 mothers breastfed their infants while receiving TCZ postpartum and provided serially sampled breastmilk between 11 hours and up to 34 days postinfusion. TCZ was present at low concentrations in all samples, with the highest reported concentration at $0.215 \mu \mathrm{g} / \mathrm{mL} 2.8$ days postinfusion. ${ }^{25}$ Only 2 studies longitudinally followed 3 infants within a range of 6 to 13 months with normal development, routine vaccinations, and no severe infections noted. ${ }^{25,26}$

In addition, a retrospective study evaluated $\mathrm{TCZ}$ treatment in 61 pregnancies in 53 mothers treated for chronic inflammatory conditions (RA, systematic idiopathic arthritis, polyarticular juvenile idiopathic arthritis, and multicentric Castleman disease) ${ }^{28} ; 2$ mothers breastfed while receiving TCZ postpartum, but further details were not reported. 


\section{Ustekinumab}

Two case reports and 1 registry prospectively followed a combined 9 pregnancies in 8 mothers treated with ustekinumab (UST) for IBD ${ }^{24,29}$ or psoriasis. ${ }^{30}$ Across all 3 studies, 8 infants were breastfed during maternal UST treatment. Two studies collected breastmilk from 7 mothers, sampled serially between 1 hour and up to 16 weeks postinfusion; some samples were collected after maintenance infusions. UST was detectable in breastmilk within the first 48 hours after infusion. ${ }^{24}$ The highest reported concentration in breastmilk, $3.2 \mu \mathrm{g} / \mathrm{mL}$, occurred 1 day postmaintenance infusion (and 16 weeks posttreatment initiation), but was observed to steadily decrease over time despite repeat infusions. ${ }^{29}$ One infant breastfed after maternal treatment was followed to 12 months of age with normal development and no severe infections. ${ }^{29}$ Longitudinal infant outcomes at 12 months were also assessed in a pooled cohort comparing development and infection rate according to breastfeeding status in 824 infants whose mothers were treated with various mAbs, including 6 mothers who all breastfed posttreatment with UST, with no significant risk observed overall. $^{24}$

\section{TNF- $\alpha$ inhibitors: adalimumab, certolizumab, golimumab, and infliximab}

\section{Adalimumab}

Three case reports and 2 prospective registries evaluated a combined 141 pregnancies in women treated with adalimumab (ADA) for psoriasis ${ }^{30}$ or IBD. ${ }^{24,31-33} \mathrm{ADA}$ was given during pregnancy in 5 mothers with no adverse pregnancy complications; however, 2 of these infants had measurable ADA at delivery in the cord and 1 day postpartum in serum, respectively. ${ }^{30-33}$ At 3 months of age, ADA was no longer detectable in the infant with measurable levels in cord blood despite breastfeeding after maternal treatment, ${ }^{31}$ and another breastfed infant had no measurable concentration in serum at 9 days. ${ }^{33}$ Cumulatively, 102 infants were breastfed during maternal ADA treatment; 24 mothers provided breastmilk samples between 1 hour and up to 9 days posttreatment, and ADA was only detectable in 17 of these samples. Concentrations in breastmilk were minimal, with the highest observed level of $0.71 \mu \mathrm{g} / \mathrm{mL}$ between 12 and 48 hours posttreatment. ${ }^{24}$ In longitudinal follow-up between 7 and 18 months, 3 infants who breastfed had no serious developmental delays or elevated rate of infection. ${ }^{31,33}$ In an additional, pooled cohort comparing development and infection rate according to breastfeeding status in 824 infants whose mothers were treated with various mAbs, including 136 treated with ADA, of which 99 continued breastfeeding, there was no significant risk observed overall. ${ }^{24}$

\section{Certolizumab}

Certolizumab is an IgG1 antibody whose FcRn transporter has been removed by the manufacturer. One study suggests that transport in the last trimester was largely blocked ${ }^{34}$-an investigation important because of the potential for prenatal transplacental exposure to confound assessment of relative monoclonal levels in the serum of mothers and nursing infants postpartum. Two case studies and 2 prospective studies have evaluated 103 pregnancies in women treated with certolizumab for chronic inflammatory diseases (RA, spondyloarthritis, Crohn disease, axial spondyloarthritis, and psoriatic arthritis). 24,34-36 More than 60 women elected to breastfeed after resuming certolizumab (CZP); 33 mothers provided 1 or several breastmilk samples between 1 hour and up to 28 days posttreatment. ${ }^{24,34-36}$ Only 16 mothers had samples with measurable CZP, reaching the highest observed concentration, $0.29 \mu \mathrm{g} / \mathrm{mL}$, within 12-48 hours posttreatment. ${ }^{24}$ One study calculated an RID (range) of $0.15(0.04-0.3) \%{ }^{34}$ No increased risk of developmental delays or elevated rate of infection was observed in 54 infants breastfed after maternal treatment with CZP in a pooled cohort comparing 12-month outcomes by breastfeeding status in 824 infants whose mothers were treated with various mAbs. ${ }^{24}$

\section{Golimumab}

In 1 prospective registry following 824 women treated with several different $\mathrm{mAbs}$ for IBD, ${ }^{24} 1$ mother was treated with golimumab (GOL) postpartum and provided serially sampled breastmilk between 1 hour and up to 7 days posttreatment. GOL was not detectable in any samples. The mother elected not to breastfeed posttreatment.

\section{Infliximab}

Eight studies prospectively followed 242 pregnancies in women treated with infliximab for IBD or psoriasis. ${ }^{24,33,37-42}$ Mothers with infliximab (IFX) treatment during pregnancy delivered healthy infants with no long-term developmental delays or increased rate of infection. ${ }^{37-41}$ One hundred seventy-nine mothers continued breastfeeding after resuming IFX postpartum; 1 mother discontinued breastfeeding after IFX was detected in infant serum 5 days following maternal treatment, but 3 other breastfed infants had no measurable IFX in serum. ${ }^{33,41}$ One other infant had IFX detected in serum at 6 weeks postpartum, and breastfeeding was temporarily stopped and later resumed, with decreasing infant IFX concentrations despite maternal retreatment and continued breastfeeding, suggesting that this was due to placental rather than breastmilk transfer. ${ }^{38}$ Forty-two mothers provided 1 or more (serial) breastmilk samples between 1 hour and up to 13 weeks posttreatment resumption; 27 women had detectable IFX levels. The highest measured concentration in breastmilk, $0.74 \mu \mathrm{g} / \mathrm{mL}$, occurred within 24-48 hours after treatment. ${ }^{24}$ One case report noted a formal immunologic evaluation of 1 infant breastfed after maternal IFX treatment at 6 months of age with normal lymphocyte subsets, IgG, IgM, IgA, and immune response to vaccines. ${ }^{38}$ No developmental delays or elevated rate of infection were observed in longitudinal follow-up of 175 breastfed infants. ${ }^{24,33,38,41}$

\section{VEGF-A inhibitors: bevacizumab and ranibizumab}

One case report and 2 case series investigated the use of bevacizumab (BVZ) and ranibizumab (RBZ) during pregnancy and breastfeeding for 8 pregnancies in 7 mothers treated for choroidal neovascularization. ${ }^{43-45}$ In 7 of the 8 pregnancies, 
mothers were treated with intravitreal BVZ injections during pregnancy, and treatment was resumed postpartum in all 8 . All pregnancies resulted in full-term, live births. Two studies reported on breastfeeding status, noting 2 infants breastfed following maternal treatment with $\mathrm{BVZ},{ }^{43,44}$ one of which was later switched to RBZ. ${ }^{44}$ Three mothers provided breastmilk sampled serially between 1 and up to 42 days postinjection; 2 mothers received several BVZ treatments, and 1 changed treatment to RBZ after 1 infusion. ${ }^{44}$ Samples were only analyzed for BVZ with no detectable concentration at any time point. ${ }^{44,45}$ One study analyzed the vascular endothelial growth factor A concentration after maternal treatment with BVZ and later RBZ, noting vascular endothelial growth factor A depletion in breastmilk post-BVZ but not RBZ. ${ }^{44}$ One of 2 infants that were breastfed after maternal treatment had normal development and no serious infections at follow-up at 12 months of age. ${ }^{43}$

\section{Discussion}

In this review, we identified a total of 30 distinct studies assessing the presence of mAbs (11 IgG1, 1 hybrid IgG2/G4, and $1 \mathrm{IgG} 4$ subclass) in human breastmilk in samples collected from a total of 155 individual women. To summarize the general trends for IgG1 mAbs evaluated (NAT differs in that it is an IgG4 subclass molecule), drug concentrations were typically low in breastmilk and drug concentrations tended to peak within 48 hours, although maximum levels could occur up to 14 days from infusion. Most studies did not evaluate the breastmilk/serum drug concentration ratio, but in those evaluating this, the highest ratio was 1:20 for infliximab. RID is a useful metric to compare the infant with maternal drug dose, although this was only evaluated in 2 studies, evaluating certolizumab and RTX, but was reassuringly $<1 \%$ in both. An RID less than $10 \%$ has generally been considered safe for an infant to breastfeed, although toxicity of the particular drug should also be considered. ${ }^{15}$ Importantly, the RID for NAT, while below the $10 \%$ commonly considered acceptable level, was estimated to be as high as $5.3 \%,^{22}$ and cumulative effects of monthly dosing are anticipated as the drug had not reached steady state by the time of the last breastmilk sample in this study. Given this, the safety of breastfeeding during NAT treatment is unclear. IgG subclass appears to be important in determining drug transfer into breastmilk, as there is greater IgG4 than IgG1 in mature breastmilk, ${ }^{46}$ explaining greater observed transfer of NAT than IgG1 mAbs such as RTX. Furthermore, a total of 368 infants were followed for at least 6 months after exposure to breastmilk of mothers treated with mAbs; none were reported to experience developmental delay or serious infections.

There were a number of limitations in this review. First, data on $\mathrm{mAb}$ use were largely derived from case reports and case series, restricting the quality rating for the evidence provided. Second, although studies were consistent in the concentrations reported across various mothers' samples, there was an overall low sample size for most mAbs studied. Third, relevant measures such as maximal concentration and RID were often unavailable.
Fourth, $\mathrm{mAb}$ concentrations were measured in maternal milk but usually not measured in the serum of exposed infants. More research is needed to better understand the transfer of IgG compounds across the infant's gut and potential systemic exposure. ${ }^{47}$ In addition, potential exposure during pregnancy should also be considered when measuring antibody levels in infant serum postpartum. Last, exposed infants were typically followed for up to 12 and 18 months, but not further into childhood and adolescence. Although the shorter-term data were reassuring, longer-term sequelae cannot be excluded.

Several mAbs were recently approved for the treatment of neurologic conditions, such as migraine, and thus far, there are limited data available to inform their presence in breastmilk, as is the case for many therapies used in neurologic conditions. ${ }^{7}$ For example, there is an increased risk of MS relapses in the postpartum period, ${ }^{48,49}$ and early resumption of effective mAb therapies could represent 1 approach to reducing this relapse risk. Along with RTX and NAT, alemtuzumab $b^{50,51}$ and ocrelizumab ${ }^{52}$ are 2 other highly effective mAbs approved for the treatment of MS, and to date, there are no published data about their presence in breastmilk. Although 3 cases of ocrelizumab exposure during lactation were reported in abstract form, concentration in breastmilk was not reported. ${ }^{53}$ Similarly, in 2018, several mAbs acting against calcitonin gene-related peptide (CGRP), or its receptor, were approved for the treatment of migraines, ${ }^{3,54,55}$ a condition that affects young adults ${ }^{56}$ and can commonly worsen during the first trimester postpartum after a period of relative quiescence. As additional $\mathrm{mAbs}$ are approved for the treatment of other conditions affecting women of childbearing age, such as NMOSD, their presence in breastmilk will also need to be ascertained.

In contrast to the limited data and lack of guidelines for use of mAbs in pregnancy or breastfeeding for neurologic conditions, prospective registries in other disciplines have improved understanding of $\mathrm{mAb}$ safety during breastfeeding such as the PIANO registry, in which mAb content in breastmilk of 72 women with inflammatory bowel disorders was measured. ${ }^{24}$ These findings were included in the American Gastrointestinal Association Institute's 2019 Clinical Decision Support Tool that recommends that biologics can be continued during breastfeeding. ${ }^{14}$ Similarly, the American College of Rheumatologists, representing another medical subspecialty that commonly prescribes mAbs, issued guidelines recommending continuation of tumor necrosis factor inhibitors (TNFi) and RTX during breastfeeding, and to consider starting or continuing non-TNFi biologics. ${ }^{13}$

Registries combining assessments of similar mAbs across disciplines and clinical indications (neurology, oncology, gastroenterology, and rheumatology), as well as compulsory postmarketing registries monitoring women who become pregnant or elect to breastfeed on treatment, could increase the number of samples available for analysis. Furthermore, these samples could also be used to determine whether the immune and metabolic profile of breastmilk differs in women with and without chronic conditions. ${ }^{57}$ Once additional data 
are available for mAb transfer into breastmilk when used in neurologic disorders, this should be incorporated into treatment guidelines in neurology. While awaiting additional studies, data presented here may provide some reassurance for low mAb transfer to breastmilk, although study of breastmilk transfer of individual therapies and effects on children is needed.

\section{Acknowledgment}

The authors acknowledge Evans Whitaker, MD, MLIS, for his guidance on the structure of this review.

\section{Study funding}

$\mathrm{RB}$ is supported by the National Multiple Sclerosis Society.

\section{Disclosure}

Dr. LaHue and Ms. Anderson report no disclosures. Dr. Krysko is funded by a Sylvia Lawry Physician Fellowship from the $\mathrm{Na}$ tional Multiple Sclerosis Society (FP-1605-08753 (Krysko)) and receives fellowship support from Biogen. Dr. Rutatangwa receives fellowship support from Biogen. Dr. Dorsey reports no disclosures. Dr. Hale is a consultant for Biogen Pharmaceuticals. Dr. Uma Mahadevan is a consultant for Janssen, AbbVie, Takeda, Gilead, Genentech, and Pfizer Dr. Rogers and Dr. Rosenstein report no disclosures. Dr. Bove has received consulting and advisory board fees from Alexion, Biogen, EMD Serono, GenzymeSanofi, Novartis, Pear Digital, and Roche-Genentech. She has received research support from Akili Interactive. The authors have no conflicts of interest relevant to this article to disclose. Go to Neurology.org/NN for full disclosures.

\section{Publication history}

Received by Neurology: Neuroimmunology \& Neuroinflammation February 11, 2020. Accepted in final form April 23, 2020.

\section{Appendix Authors}

\begin{tabular}{|c|c|c|}
\hline Name & Location & Contribution \\
\hline $\begin{array}{l}\text { Sara C. LaHue, } \\
\text { MD }\end{array}$ & $\begin{array}{l}\text { University of } \\
\text { California, San } \\
\text { Francisco }\end{array}$ & $\begin{array}{l}\text { Designed and conceptualized the } \\
\text { review; analyzed and interpreted } \\
\text { the data; and drafted the } \\
\text { manuscript for intellectual content }\end{array}$ \\
\hline $\begin{array}{l}\text { Annika } \\
\text { Anderson, BA }\end{array}$ & $\begin{array}{l}\text { University of } \\
\text { California, San } \\
\text { Francisco }\end{array}$ & $\begin{array}{l}\text { Major role in acquisition of data } \\
\text { and revised the manuscript for } \\
\text { intellectual content }\end{array}$ \\
\hline $\begin{array}{l}\text { Kristen M. } \\
\text { Krysko, MD, } \\
\text { MAS }\end{array}$ & $\begin{array}{l}\text { University of } \\
\text { California, San } \\
\text { Francisco }\end{array}$ & $\begin{array}{l}\text { Major role in acquisition of data; } \\
\text { analyzed and interpreted the data; } \\
\text { and revised the manuscript for } \\
\text { intellectual content }\end{array}$ \\
\hline $\begin{array}{l}\text { Alice } \\
\text { Rutatangwa, } \\
\text { DO }\end{array}$ & $\begin{array}{l}\text { University of } \\
\text { California, San } \\
\text { Francisco }\end{array}$ & $\begin{array}{l}\text { Interpreted the data and revised } \\
\text { the manuscript for intellectual } \\
\text { content }\end{array}$ \\
\hline $\begin{array}{l}\text { Morna J. } \\
\text { Dorsey, MD, } \\
\text { MMSc }\end{array}$ & $\begin{array}{l}\text { University of } \\
\text { California, San } \\
\text { Francisco }\end{array}$ & $\begin{array}{l}\text { Interpreted the data and revised } \\
\text { the manuscript for intellectual } \\
\text { content }\end{array}$ \\
\hline $\begin{array}{l}\text { Thomas Hale, } \\
\text { RPh, PhD }\end{array}$ & $\begin{array}{l}\text { Texas Tech } \\
\text { University }\end{array}$ & $\begin{array}{l}\text { Interpreted the data and revised } \\
\text { the manuscript for intellectual } \\
\text { content }\end{array}$ \\
\hline
\end{tabular}

Appendix (continued)

\begin{tabular}{lll}
\hline Name & Location & Contribution \\
\hline $\begin{array}{l}\text { Uma } \\
\text { Mahadevan, }\end{array}$ & $\begin{array}{l}\text { University of } \\
\text { California, San } \\
\text { Francisco }\end{array}$ & $\begin{array}{l}\text { Interpreted the data and revised } \\
\text { the manuscript for intellectual } \\
\text { content }\end{array}$ \\
\hline $\begin{array}{l}\text { Elizabeth E. } \\
\text { Rogers, MD }\end{array}$ & $\begin{array}{l}\text { University of } \\
\text { California, San } \\
\text { Francisco }\end{array}$ & $\begin{array}{l}\text { Interpreted the data and revised } \\
\text { the manuscript for intellectual } \\
\text { content }\end{array}$ \\
$\begin{array}{l}\text { Melissa G. } \\
\text { Rosenstein, } \\
\text { MD, MAS }\end{array}$ & $\begin{array}{l}\text { University of } \\
\text { California, San }\end{array}$ & $\begin{array}{l}\text { Interpreted the data and revised } \\
\text { the manuscript for intellectual } \\
\text { content }\end{array}$ \\
\hline $\begin{array}{l}\text { Riley Bove, } \\
\text { MD, MSc }\end{array}$ & $\begin{array}{l}\text { University of } \\
\text { California, San } \\
\text { Francisco }\end{array}$ & $\begin{array}{l}\text { Designed and conceptualized the } \\
\text { review; major role in acquisition of } \\
\text { data; analyzed and interpreted the } \\
\text { data; and revised the manuscript } \\
\text { for intellectual content }\end{array}$ \\
& &
\end{tabular}

\section{References}

1. Almas S, Vance J, Baker T, Hale T. Management of multiple sclerosis in the breastfeeding mother. Mult Scler Int 2016;2016:6527458.

2. Loder EW, Burch RC. Who should try new antibody treatments for migraine? JAMA Neurol 2018;75:1039-1040.

3. Loder EW, Robbins MS. Monoclonal antibodies for migraine prevention: progress, but not a panacea. JAMA 2018;319:1985-1987.

4. Mantegazza R, Antozzi C. When myasthenia gravis is deemed refractory: clinical signposts and treatment strategies. Ther Adv Neurol Disord 2018;11: 1756285617749134 .

5. Stieglbauer K, Pichler R, Topakian R. 10-year-outcomes after rituximab for myasthenia gravis: efficacy, safety, costs of inhospital care, and impact on childbearing potential. J Neurol Sci 2017;375:241-244.

6. Novak JC, Lovett-Racke AE, Racke MK. Monoclonal antibody therapies and neurologic disorders. Arch Neurol 2008;65:1162-1165.

7. LaHue SC, Gelfand AA, Bove RM. Navigating monoclonal antibody use in breastfeeding women: do no harm or do little good? Neurology 2019;93:668-672.

8. Anderson PO, Sauberan JB. Modeling drug passage into human milk. Clin Pharmacol Ther 2016;100:42-52.

9. Hurley WL, Theil PK. Perspectives on immunoglobulins in colostrum and milk. Nutrients 2011;3:442-474.

10. Jasion VS, Burnett BP. Survival and digestibility of orally-administered immunoglobulin preparations containing $\operatorname{IgG}$ through the gastrointestinal tract in humans. Nutr J 2015;14:22.

11. Giragossian C, Clark T, Piche-Nicholas N, Bowman CJ. Neonatal Fc receptor and its role in the absorption, distribution, metabolism and excretion of immunoglobulin G-based biotherapeutics. Curr Drug Metab 2013;14:764-790.

12. Breastfeeding and the use of human milk. Pediatrics 2012;129:e827-841.

13. Rheumatology ACo. Reproductive Health in Rheumatic Diseases [online]. Available at: rheumatology.org/Practice-Quality/Clinical-Support/Clinical-PracticeGuidelines/Reproductive-Health-in-Rheumatic-Diseases. Accessed October 16, 2019.

14. Mahadevan U, Robinson C, Bernasko N, et al. Inflammatory bowel disease in pregnancy clinical care pathway: a report from the American Gastroenterological Association IBD Parenthood Project Working Group. Am J Obstet Gynecol 2019;220:308-323.

15. Bennett P. Drugs and Human Lactation: A Comprehensive Guide to the Content and Consequences of Drugs, Micronutrients, Radiopharmaceuticals and Environmental and Occupational Chemicals in Human Milk. 2nd ed. Amsterdam, The Netherlands: Elsevier; 1996.

16. Bragnes Y, Boshuizen R, de Vries A, Lexberg A, Ostensen M. Low level of Rituximab in human breast milk in a patient treated during lactation. Rheumatology (Oxford) 2017;56:1047-1048.

17. Krysko KM, LaHue SC, Anderson A, et al. Minimal breast milk transfer of rituximab, a monoclonal antibody used in neurological conditions. Neurol Neuroimmunol Neuroinflamm 2020;7:e637. 10.1212/NXI.0000000000000637.

18. Kelly RJ, Hochsmann B, Szer J, et al. Eculizumab in pregnant patients with paroxysmal nocturnal hemoglobinuria. N Engl J Med 2015;373:1032-1039.

19. Ross E, Robinson SE, Amato C, et al. Therapeutic monoclonal antibodies in human breast milk: a case study. Melanoma Res 2014;24:177-180.

20. Julsgaard M, Kjeldsen J, Bibby BM, Brock B, Baumgart DC. Vedolizumab concentrations in the breast milk of nursing mothers with inflammatory bowel disease. Gastroenterology 2018;154:752-754.e751.

21. Lahat A, Shitrit AB, Naftali T, et al. Vedolizumab levels in breast milk of nursing mothers with inflammatory bowel disease. J Crohns Colitis 2018;12:120-123.

22. Baker TE, Cooper SD, Kessler L, Hale TW. Transfer of natalizumab into breast milk in a mother with multiple sclerosis. J Hum Lact 2015;31:233-236. 
23. Proschmann U, Thomas K, Thiel S, Hellwig K, Ziemssen T. Natalizumab during pregnancy and lactation. Mult Scler 2018;24:1627-1634.

24. Matro R, Martin CF, Wolf D, Shah SA, Mahadevan U. Exposure concentrations of infants breastfed by women receiving biologic therapies for inflammatory bowel diseases and effects of breastfeeding on infections and development. Gastroenterology 2018;155:696-704.

25. Saito J, Yakuwa N, Kaneko K, et al. Tocilizumab during pregnancy and lactation: drug levels in maternal serum, cord blood, breast milk and infant serum. Rheumatology (Oxford) 2019;58:1505-1507.

26. Saito J, Yakuwa N, Takai C, et al. Tocilizumab concentrations in maternal serum and breast milk during breastfeeding and a safety assessment in infants: a case study. Rheumatology (Oxford) 2018;57:1499-1501.

27. Saito J, Yakuwa N, Kaneko K, et al. Clinical application of the dried milk spot method for measuring tocilizumab concentrations in the breast milk of patients with rheumatoid arthritis. Int J Rheum Dis 2019;22:1130-1137.

28. Nakajima K, Watanabe O, Mochizuki M, Nakasone A, Ishizuka N, Murashima A. Pregnancy outcomes after exposure to tocilizumab: a retrospective analysis of 61 patients in Japan. Mod Rheumatol 2016;26:667-671.

29. Klenske E, Osaba L, Nagore D, Rath T, Neurath MF, Atreya R. Drug levels in the maternal serum, cord blood and breast milk of a ustekinumab-treated patient with Crohn's disease. J Crohns Colitis 2019;13:267-269.

30. Mugheddu C, Atzori L, Lappi A, Murgia S, Rongioletti F. Biologics exposure during pregnancy and breastfeeding in a psoriasis patient. Dermatol Ther 2019;32:e12895.

31. Julsgaard M, Brown S, Gibson P, Bell S. Adalimumab levels in an infant. J Crohns Colitis 2013;7:597-598.

32. Ben-Horin S, Yavzori M, Katz L, et al. Adalimumab level in breast milk of a nursing mother. Clin Gastroenterol Hepatol 2010;8:475-476.

33. Fritzsche J, Pilch A, Mury D, Schaefer C, Weber-Schoendorfer C. Infliximab and adalimumab use during breastfeeding. J Clin Gastroenterol 2012;46:718-719.

34. Clowse ME, Forger F, Hwang C, et al. Minimal to no transfer of certolizumab pegol into breast milk: results from CRADLE, a prospective, postmarketing, multicentre, pharmacokinetic study. Ann Rheum Dis 2017;76:1890-1896.

35. Morita T, Fujimoto K, Shima Y, Ogata A, Kumanogoh A. Minimal neonatal transfer of certolizumab pegol in a Japanese patient with rheumatoid arthritis. Ann Rheum Dis 2018;77:e56.

36. Forger F, Zbinden A, Villiger PM. Certolizumab treatment during late pregnancy in patients with rheumatic diseases: low drug levels in cord blood but possible risk for maternal infections. A case series of 13 patients. Joint Bone Spine 2016;83:341-343.

37. Stengel JZ, Arnold HL. Is infliximab safe to use while breastfeeding? World J Gastroenterol 2008;14:3085-3087.

38. Vasiliauskas EA, Church JA, Silverman N, Barry M, Targan SR, Dubinsky MC. Case report: evidence for transplacental transfer of maternally administered infliximab to the newborn. Clin Gastroenterol Hepatol 2006;4:1255-1258.

39. Puig L, Barco D, Alomar A. Treatment of psoriasis with anti-TNF drugs during pregnancy: case report and review of the literature. Dermatology 2010;220:71-76.

40. Grosen A, Julsgaard M, Kelsen J, Christensen LA. Infliximab concentrations in the milk of nursing mothers with inflammatory bowel disease. J Crohns Colitis 2014;8:175-176.
41. Kane S, Ford J, Cohen R, Wagner C. Absence of infliximab in infants and breast milk from nursing mothers receiving therapy for Crohn's disease before and after delivery. J Clin Gastroenterol 2009;43:613-616.

42. Ben-Horin S, Yavzori M, Kopylov U, et al. Detection of infliximab in breast milk of nursing mothers with inflammatory bowel disease. J Crohns Colitis 2011;5:555-558.

43. Tarantola RM, Folk JC, Boldt HC, Mahajan VB. Intravitreal bevacizumab during pregnancy. Retina 2010;30:1405-1411.

44. Ehlken C, Martin G, Stahl A, Agostini HT. Reduction of vascular endothelial growth factor a in human breast milk after intravitreal injection of bevacizumab but not ranibizumab. Arch Ophthalmol 2012;130:1226-1227.

45. McFarland TJ, Rhoads AD, Hartzell M, Emerson GG, Bhavsar AR, Stout JT. Bevacizumab levels in breast milk after long-term intravitreal injections. Retina 2015;35: 1670-1673.

46. Rodriguez-Camejo C, Puyol A, Fazio L, et al. Antibody profile of colostrum and the effect of processing in human milk banks: implications in immunoregulatory properties. J Hum Lact 2018;34:137-147.

47. Kane SV, Acquah LA. Placental transport of immunoglobulins: a clinical review for gastroenterologists who prescribe therapeutic monoclonal antibodies to women during conception and pregnancy. Am J Gastroenterol 2009;104:228-233.

48. Confavreux C, Hutchinson M, Hours MM, Cortinovis-Tourniaire P, Moreau T. Rate of pregnancy-related relapse in multiple sclerosis. Pregnancy in Multiple Sclerosis Group. N Engl J Med 1998;339:285-291.

49. Bove R, Alwan S, Friedman JM, et al. Management of multiple sclerosis during pregnancy and the reproductive years: a systematic review. Obstet Gynecol 2014;124:1157-1168.

50. Cohen JA, Coles AJ, Arnold DL, et al. Alemtuzumab versus interferon beta 1a as firstline treatment for patients with relapsing-remitting multiple sclerosis: a randomised controlled phase 3 trial. Lancet 2012;380:1819-1828.

51. Coles AJ, Twyman CL, Arnold DL, et al. Alemtuzumab for patients with relapsing multiple sclerosis after disease-modifying therapy: a randomised controlled phase 3 trial. Lancet 2012;380:1829-1839.

52. Hauser SL, Bar-Or A, Comi G, et al. Ocrelizumab versus interferon beta-1a in relapsing multiple sclerosis. N Engl J Med 2017;376:221-234.

53. Oreja-Guevara C, Wray S, Buffels R, Zecevic D, Vukusic S. Pregnancy Outcomes in Patients Treated With Ocrelizumab [abstract]. Stockholm: ECTRIMS; 2019.

54. Burch R, Rayhill M. New preventive treatments for migraine. BMJ 2018;361:k2507.

55. Oakes TMM, Skljarevski V, Zhang $Q$ et al. Safety of galcanezumab in patients with episodic migraine: a randomized placebo-controlled dose-ranging Phase $2 \mathrm{~b}$ study. Cephalalgia 2018;38:1015-1025.

56. Group GBDNDC. Global, regional, and national burden of neurological disorders during 1990-2015: a systematic analysis for the Global Burden of Disease Study 2015. Lancet Neurol 2017;16:877-897.

57. Meng X, Dunsmore G, Koleva P, et al. The profile of human milk metabolome, cytokines, and antibodies in inflammatory bowel diseases versus healthy mothers, and potential impact on the newborn. J Crohns colitis 2019;13:431-441.

Reference e1-e31 are available at links.lww.com/NXI/A260. 


\title{
Neurology \\ Neuroimmunology \& Neuroinflammation
}

\author{
Transfer of monoclonal antibodies into breastmilk in neurologic and non-neurologic \\ diseases \\ Sara C. LaHue, Annika Anderson, Kristen M. Krysko, et al. \\ Neurol Neuroimmunol Neuroinflamm 2020;7; \\ DOI 10.1212/NXI.0000000000000769
}

This information is current as of May 27, 2020

\section{Updated Information \& Services}

References

Citations

Subspecialty Collections

Permissions \& Licensing

Reprints including high resolution figures, can be found at:

http://nn.neurology.org/content/7/4/e769.full.html

This article cites 54 articles, 3 of which you can access for free at: http://nn.neurology.org/content/7/4/e769.full.html\#\#ref-list-1

This article has been cited by 4 HighWire-hosted articles: http://nn.neurology.org/content/7/4/e769.full.html\#\#otherarticles

This article, along with others on similar topics, appears in the following collection(s):

Autoimmune diseases

http://nn.neurology.org//cgi/collection/autoimmune_diseases Multiple sclerosis

http://nn.neurology.org//cgi/collection/multiple_sclerosis

Information about reproducing this article in parts (figures,tables) or in its entirety can be found online at:

http://nn.neurology.org/misc/about.xhtml\#permissions

Information about ordering reprints can be found online:

http://nn.neurology.org/misc/addir.xhtml\#reprintsus

Neurol Neuroimmunol Neuroinflamm is an official journal of the American Academy of Neurology.

Published since April 2014, it is an open-access, online-only, continuous publication journal. Copyright

Copyright (C) 2020 The Author(s). Published by Wolters Kluwer Health, Inc. on behalf of the American

Academy of Neurology.. All rights reserved. Online ISSN: 2332-7812.

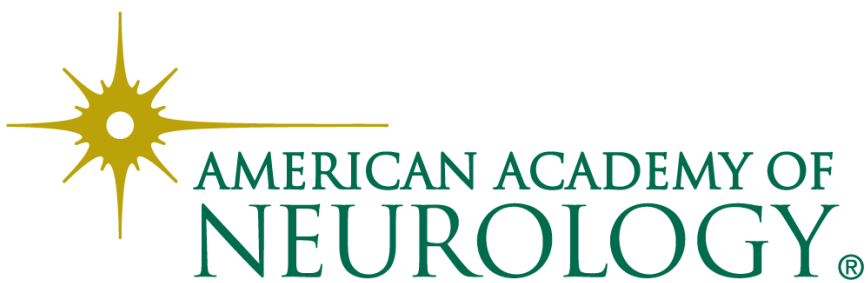

